\title{
Knowledge as the Working and Walking Narrative ${ }^{[*]}$
}

\section{Çalıșma ve Gezme Anlatısı Olarak Bilgi}

\author{
FEMI RICHARD OMOTOYINBO (D) \\ Independent Researcher
}

Received: I3.II.2OI8 | Accepted: 23.I2.20I8

\begin{abstract}
Motion' in the acquisition of knowledge is the focus of this paper. My claim is that the motion in the acquisition of knowledge, albeit abstract, is of two dimensions: one as 'the mind working towards reality' and the other as 'reality walking towards the mind'. Using an epistemic approach, I conceptualize these two dimensions (hereafter as the working and walking narrative) under the Externalism and the Internalism divide and identify that externalism leaves us with more to explore about knowledge acquisition than internalism. Since externalism seems to accommodate the two dimensions better than internalism, I present the working and walking narrative under externalism. Two envisaged objections are addressed, along with considerations of some probable implications of the working and walking narrative for philosophy, specifically epistemology.
\end{abstract}

Keywords: Epistemic effort, knowledge acquisition, externalism, internalism, dual carriageway of knowing. 


\section{Introduction}

Knowledge, to Linda Zagzebski, is "cognitive contact with reality arising out of acts of intellectual virtue (Zagzebski, I999: I09).” This definition may not be epistemologically overarching, but it serves the purpose of this paper because of the contents: 'cognitive contact' and 'acts of intellectual virtue'. By 'cognitive contact', the Zagzebski's definition of knowledge shows that knowledge is, more or less, an outcome of the connection between mind and reality. 'Acts of intellectual virtue' further suggests that the connection between mind and reality occurs through the conscious efforts of an intelligent being (i.e., an epistemic entity or agent). Both contents further imply that there is $\operatorname{motion}^{\mathrm{I}}$ in the acquisition of knowledge. That is, there is a movement of the mind towards reality based on the effort of an epistemic entity. While it is true that knowledge could result as a connection between the knower (mind) and the known (reality), I reckon that the connection could occur without the conscious effort of an epistemic entity. Moreover, a proper grasp of the motion in the acquisition of knowledge would be useful to reveal other possibility in which there is no conscious effort of an epistemic entity in the acquisition of knowledge. Thus, this paper is having four main sections. The first section explores the externalism and internalism divide for an appropriate conceptualisation of the motion in the acquisition of knowledge. The second section puts more emphasis on externalism going by its potentials to accommodate the two dimensions of motion (i.e., the working and walking narrative). Here, I will flesh out the working and walking narrative. In the third section, two possible objections to the working and walking narrative will be addressed; and the fourth section will be used to consider some probable implications of the narrative.

\section{The Externalism and Internalism Divide}

The externalism and internalism divide is part of contemporary epistemology, and it relates to both justification and knowledge. Externalism, for instance, is the view that knowledge or justification (as the case may be) involves external factors and not just the internal states of the know-

\footnotetext{
I This is a non-physical motion having more connection with the process motion in Aztec Philosophy than the substance motion in Western Philosophy. See Maffie, 2014.
} 
er. Internalism is the opposite view that knowledge or justification wholly depends on the internal states of the knower. Nevertheless, the scope of this paper concerns the externalism and internalism divide as it relates to knowledge.

Both externalists and internalists admit that knowledge is an outcome of the connections between the knower (mind) and the known (reality), and that the connections could happen via various sources (e.g. experience, intuition, reason, testimony etc.). However, a major difference between externalism and internalsim is on the knower's effort in the acquisition knowledge. For externalism, on one side of the divide, knowledge acquisition can be through the influences of people and other activities around, apart from the conscious efforts of the knower (Greco, 2004: 53). In other words, there could be knowledge acquisition with or without the efforts of an epistemic agent. On the other side, internalism is the claim that knowledge acquisition is mainly within the cognitive circumference or limit of the epistemic agent. There is knowledge iff ${ }^{2}$ its acquisition is totally influenced by the knower's conscious effort and not by the influence of external factors (Sosa, I999: I48-150).

To put the above into context, we can say that both externalism and internalism acknowledge that there is motion prior to the connection between the mind (the knower) and reality (the known). As earlier mentioned, this kind of motion is not necessarily the spatio-temporal motion of substances. It is rather an abstract motion in terms of (epistemic) processes (e.g., thinking, experimentation, introspection or observation) through which the mind connects with reality. We can liken this motion to the extension of the mind towards reality or vice-versa. The dissimilarity between externalism and internalism (in this context) is on the dimension(s) of the motion. While externalism takes the motion to be of two dimensions, internalism considers it as of a single dimension. Recall the externalists' view that knowledge acquisition could be through external factors and not only through the knower's effort. Thus, for externalism, the motion in the acquisition of knowledge is of two dimensions: one dimension of the motion is through the knower's effort, and the other

2 Iff is a philosophical symbol indicating if and only if. 
dimension is through external factors. I will elaborate on this soon. Internalism restricts the acquisition of knowledge as only through the internal states of the knower. It therefore makes motion to be onedimensional; that is, only through the knower's effort. I will not continue to explore internalism, but to anticipate possible query, I will rather say that internalism is restrictive and (we would soon see that) it cannot satisfy the purpose of this paper. It is this restriction, among other things, that externalism rejects (Alston, 2004: 38). Therefore, the next section will put emphasis on externalism because it is more appealing, specifically for the purpose of this paper.

\section{Externalism and the working and walking narrative}

Further emphasis on externalism (in this section) is to show how it serves the purpose of this paper and to clearly flesh out the working and walking narrative.

Externalism is more appealing here because it maintains that knowledge acquisition is possible via external factors, but it does not deny the possibilities of acquiring knowledge through the internal states of the knower. It simply rejects the claim that knowledge acquisition is only through internal states of the knower. This enables externalism to accommodate the claim that the motion in knowledge acquisition is of two dimensions. As mentioned above, one dimension is through the knower's effort while the other dimension is without the knower's effort. To elaborate further, knowledge is indeed the outcome of connections between the mind and reality, and 'motion' is the process through which the connections occur. In terms of 'motion', externalism provides us with a dual carriageway of knowing as shown in Figure $I$ below. Motion in one dimension is through the knower's effort, in which the mind connects with reality.

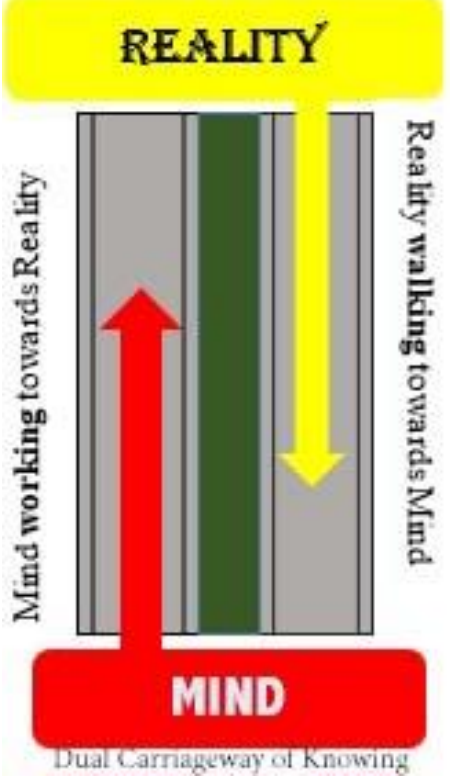


Motion in another dimension is through external factors, whereby reality connects with the mind. I conceptualize these two dimensions of motion as the working and walking narrative. Whereas the first dimension is about the mind literally 'working' towards reality, the other dimension is about reality figuratively 'walking' towards the mind. For the sake of clarity I will now begin explanation of the working and walking narrative, starting with the 'working' dimension of the narrative. It is needful for the reader to keep in mind that by narrative, the connotation is simply the method of passing across a message or providing some clear or new perception of something.

\section{I. The Working Dimension}

Following the classical conception of knowledge as Justified True Belief (JTB) and its attack from Gettier (I963: I2I-I23), it has become a challenge for epistemologists to devise a most plausible notion of knowledge. It is likely that efforts are still on, but to this extent, some of the efforts subscribe to giving primacy to the knower in the acquisition of knowledge. To them, there is an acquisition of knowledge if the knower is having reflective access to evidence(s) or if there is a cooperation between the knower and the world ${ }^{3}$. The burden of knowing is significantly on the knower because knowledge is impossible if she fails to take 'essential' actions for its acquisition. This echoes Pritchard's description of knowledge as a "cognitive success" achieved by a knower (Pritchard, 2OI4: 55). I consider this well-known epistemic situation in which the knower takes some actions in order to acquire knowledge as the 'working' dimension in the narrative. It means that without the knower, there are no epistemic actions and without epistemic actions, the acquisition of knowledge will be impossible. Just as a cook gathers the ingredients and utensils in order to make food, the knower (as the mind) takes some actions (e.g. observes, reflects and examines) in order to connect with reality. In short, the implication is that there is a 'cognitive contact' with reality when the mind (knower) literally works for it. Apart from the knower (the mind), three other essential elements are present in the working dimension of the narrative.

3 See Plantinga, I993: 8, I0; Lehrer \& Truncellito, 2004: I69. 
They are:

(A) The 'epistemic action'

(B) The epistemic action is deliberate (conscious) and

(C) There is connection between mind and reality.

The three elements indicate that for knowledge to be acquired, the knower takes an epistemic action with a conscious desire to connect with reality, and not reality connecting with her mind.

\subsection{The Walking Dimension}

In the 'walking' dimension of the narrative, the third element (C) above is present although the first (A) and the second (B) elements are irrelevant. Additionally, the presence of the knower is also important for knowledge acquisition but in a different way. Here, the knower is mainly a recipient of knowledge and the connection between the mind and reality is not depending on her efforts. Her presence is important for knowledge to have a dwelling (in her mind) but her conscious epistemic actions do not determine the acquisition of knowledge. Using the cook example here again, we might say that the cook (the knower) simply finds that the food (knowledge) is already available or prepared without her cooking it (working to connect with reality). A closer analogy is Kay standing under a roof and cold water trickles on him from the roof; he thereby knows that the water is cold, but the acquisition of this knowledge is not through his epistemic effort. He, ceteris paribus, does not need to work (i.e. think, observe) to realise that the trickling water is cold. The acquisition of the knowledge that the trickling water is cold differs from when Kay reads from books or consciously takes steps to know that the water is cold. While in the working dimension the mind connects with reality, in the walking dimension reality itself connects with the mind. It is as if reality has legs and it takes steps with those legs in order to connect with the mind. This shows that the knower (mind) is not exerting epistemic effort to connect with reality, but external factors could influence reality to walk towards the mind. Notice that a distinctive feature of the walking dimension is that there is no epistemic effort from the knower and reality is incapable of exerting epistemic actions (working), so it walks. Instances of the walking dimension are often present in Testi- 
mony ${ }^{4}$. For example, I know that President Donald Trump is currently the head of the United States government not because I witnessed his inauguration, but the source of my knowledge is testimony (from the media). I acquire the knowledge without epistemic effort because I belong to a community of knowers whose knowledge guarantees my knowledge of Trump's presidential position. There are also instances of the walking dimension in epistemic luck, among others (Pritchard, 2004: I96-7).

To this extent, I present the working and walking narrative as a novel way of explaining the (two dimensions of motion in the) acquisition of knowledge. In the context of the working and walking narrative, we can define knowledge as an outcome of the connection of mind with reality (i.e., the working dimension) and/or the connection of reality with mind (i.e., the walking dimension). This is a radical shift from the view that knowing or knowledge is only possible when mind connects with reality. I strongly suggest that the working and walking narrative is very appropriate to differentiate and explain the dimensions of motion involved in the acquisition of knowledge. If knowledge is indeed a "cooperative enterprise" (Lehrer \& Truncellito, 2004: I69), it is more reasonable to envisage its acquisition as of two dimensions rather than one dimension. It is important for Philosophers to affirm these distinctions in the acquisition of knowledge and admit both as equally plausible. This could widen the horizon of epistemology as a subset of philosophy. I will consider this and other probable implications of the working and walking narrative later in this paper. Meanwhile, I will first address two possible objections to the working and walking narrative.

\section{Two Objections to the Working and Walking Narrative}

There are two major objections to the working and walking narrative; one is from the internalists and the other is from the sceptics.

\section{I. The Internalists' Attack}

The argument of the internalists is against the walking dimension of the narrative. The internalists would argue that there is no knowledge

\footnotetext{
4 The speech-act theory of testimony is most apt here. See Welbourne, I986: 33.
} 
without the epistemic actions or the internal states of the knower. The conscious epistemic actions or the internal states are not just some characteristics of knowing but they majorly distinguish knowledge from beliefs or mere dogmas. Through her epistemic actions, a knower is able to ascertain the genuineness of her knowledge. It is through the epistemic actions that the knower is able to sieve out non-knowledge elements (like falsehood, assumptions, beliefs etc) from knowledge itself. Given this claim, the internalists' attack is that the absence of the conscious epistemic actions or the internal states of the knower, in the walking dimension of the narrative, makes it difficult to distinguish the acquired knowledge from beliefs or mere dogmas. Therefore, it is acceptable to claim that whatever is acquired through the walking dimension is either not knowledge, a pseudo-knowledge or what Sosa would call 'animal knowledge's.

My reaction to the internalists is that a rigid emphasis on the epistemic actions or internal states of the knower in the acquisition of knowledge is a blind denial of various possibilities in knowledge acquisition. The claim that the epistemic actions of the knower is essential implies that the knower should be in control of the acquisition of knowledge. She conditions her mind to connect with reality, and if she wishes, she may not allow her mind to connect with certain realities. If this is true, it means that people only know what they choose to know, since they normally would not like to invest their epistemic efforts to acquire some painful or uninteresting knowledge. For example, a wife may not like to know that the husband is cheating on her, and an employee would not wish to know that she would soon lose her job. But they do know notwithstanding their possible preference for ignorance. Are we then to deny that they know because their knowledge does not result through their epistemic actions? They probably know via testimony or epistemic luck and their knowledge is genuine even without their epistemic efforts. To hold the internalists' objection as true is tantamount to narrowing down conceivable epistemic possibilities in the acquisition of knowledge.

5 For Sosa's further conception of 'animal knowledge' and its distinction from 'reflective knowledge', see Sosa, I991: 225-244. 


\subsection{The Sceptics' Objection}

A kind of scepticism that is averse to the working and walking narrative is the anarchist version that popularly denies the possibility of knowledge. This version of scepticism denies the two dimensions of knowledge acquisition ipso facto that it denies knowledge. In other words, the substance of the sceptics' objection is that if there is no knowledge then it is pointless to conceive some dimensions of its acquisition.

To reply the objection of the sceptics, I would attempt a pardonable argument ad hominem ${ }^{6}$ to show that the objection of the sceptics is selfrefuting. An important question is that: Do the sceptics know that there is no knowledge or they believe that there is no knowledge? I assume that the sceptics would prefer to say that they know there is no knowledge because it gives more certainty to their claim than to say that they (simply) believe that there is no knowledge. At least in epistemology, 'to know' is usually in stronger terms than 'to believe'. However, if the sceptics claim that they know that there is no knowledge it means their denial of knowledge (scepticism) is 'knowledge' to them. My point is that if 'scepticism' is knowledge to sceptics, then there is (at least one) knowledge. If there is (at least one) knowledge then scepticism is false, and the dimensions of knowledge acquisition (i.e., working and walking narrative) remain unrefuted by scepticism. Consequently, I will use the next section to consider some possible implications of the working and walking narrative.

\section{Potential Implications of the Working and Walking Narrative}

In this section, I will be considering some probable implications of the working and walking narrative for philosophy, specifically epistemology. At a glance, the working and walking narrative has the implication of using Ockham's razor to present the two dimensions of motion in the acquisition of knowledge. Thus, the working and walking narrative is apparently a simpler explanation of the motion in the acquisition of

\footnotetext{
${ }^{6}$ Argument ad hominem is a fallacy in logical argumentation meaning "argument against the person". It usually involves the rejection of a person's claim because of her attributes or traits. An example is to reject Susie's argument that smoking is bad because Susie herself is a chain-smoker. Pardonable versions of Argument ad hominem (as used in the sceptics' objection) include a rejection of a person's claim because of inconsistencies of the claim with some related claims of the person.
} 
knowledge. This further has a pedagogical implication in which it endorses a simpler and clearer explanation of the nature of knowledge acquisition that is comprehensible (or even apprehensible) for non-philosophers or new entrants to the philosophical guild.

Another implication is that the working and walking narrative is a further shift from traditional epistemology, which is somewhat anthropocentric because it gives primacy to human beings (the epistemic agents) in the matters of knowledge. In the working and walking narrative, knowledge is not wholly under the auspices of human beings (epistemic agents), at least in terms of acquisition. Knowledge is rather a multidimensional social phenomenon: it could be an outcome of various connections involving man and even going beyond man's cranium or epistemic efforts to include social factors. Thus, the working and walking narrative pictures knowledge as either an 'entity' or a concept with inexhaustible possibilities.

Additionally, the working and walking narrative is useful to understand and explain knowledge in anomalous contexts. This implication is more applicable under Philosophy of mind, Cognitive science, and Artificial intelligence. I will briefly consider two of such anomalous contexts. One is in the case of babies or infants, which we may consider as simple epistemic agents because they are not epistemically sophisticated like a fullgrown human being. Although they are potential epistemic agents, but they are presently unable to exert their epistemic efforts in the same way as adults who are complex epistemic agents. If knowledge is only possible when mind connects with reality, it may be difficult to consider simple epistemic agents as capable of knowing. Nonetheless, the working and walking narrative is useful to understand the peculiarities of the knowledge of simple epistemic agents e.g., infants - especially in terms of reality connecting to their minds (Spokes \& Spelke, 2OI7: IO2-II6).

Another anomalous context is the case of artificial intelligence or simulation in which robots or automatons exhibit acts of intelligence that suggest the presence of knowledge. How do we explain the knowledge of robots if they are not epistemic agents per se? A brief explanation, derivable from the working and walking narrative, is that the non-human entities (robots, Artificial Linguistic Internet Computer Entities [ALICEs] 
etc.) have an artificial model of the two dimensions of motion in the acquisition of knowledge installed in them. They, therefore, could connect with reality and reality could connect with them almost like real epistemic agents that have minds. I envision that the working and walking narrative could also have related implications in philosophy of simulation and epistemology of simulation ${ }^{7}$ respectively. These are however beyond the scope of this paper.

A final implication that I will mention here is that the working and walking narrative, specifically the walking dimension, could expand epistemology (as a discipline) to accommodate non-western epistemic dialogues. Remember that (western) epistemology favours the working dimension; it almost make the knower's internal state as sufficient for the acquisition of knowledge. The inclusion of the walking dimension would enable epistemology to contain other epistemic world-views like the African theory of knowledge, which considers "other variables [apart from the knower's internal states] playing roles in the process of cognition/knowing" (Jimoh, 2OI7: I2I-I36). This would help epistemologists to identify and explore other means (like divination, revelation/astral projection, and traditional folklores) through which reality could connect with mind.

\section{Conclusion}

What has been done so far is to explain my claim that the connections between mind and reality, on one hand, and between reality and mind, on the other hand, suggest that there is a dual-dimensional 'motion' in the acquisition of knowledge. I used the working and walking narrative to present the two dimensions under externalism, and described knowledge as an outcome of the connection of mind with reality (the working dimension) and/or the connection of reality with mind (the walking dimension). Following this expanded description of knowledge, I addressed two envisaged objections from the internalists and the sceptics respectively. I considered some philosophical and epistemic implications

For more on Philosophy of simulation and Epistemology of Simulation, see: Frigg R. \& Reiss J. (2009). The Philosophy of Simulation. Synthese, I69, 53-613. And Winsberg E. (1999). Sanctioning Models: The Epistemology of Simulation. Science in Context, I2:2, 275297. 
of the working and walking narrative, to show, among other things, that epistemology has more benefits to derive from the working and walking narrative.

\section{References}

Alston, W. P. (2004). The Challenge of Externalism. The Externalist Challenge, vol. 2. (Ed. R. Schantz). New York: Walter de Gruyter, 37-52.

Gettier, E. (1963). Is Justified Belief Knowledge? Analysis, 23 (6), I2I-I23.

Greco, J. (2004). Externalism and Scepticism. The Externalist Challenge, vol. 2. (Ed. R. Schantz). New York: Walter de Gruyter, 53-64.

Jimoh, A. K. (2017). An African Theory of Knowledge. Themes, Issues and Problems in African Philosophy. (Ed. I. E. Ukpokolo). Cham: Palgrave Macmillan, I2I136.

Lehrer, K., \& Truncellito, D. A. (2004). Knowledge, Justification and the Cooperative World. The Externalist Challenge, vol. 2. (Ed. R. Schantz). New York: Walter de Gruyter, I69-I80.

Pritchard, D. (2004). Epistemic Luck. Fournal of Philosophical Research, 29, 199-222.

Pritchard, D. (2014). What is This Thing Called Knowledge? New York: Routledge.

Sosa, E. (1999). Skepticism and the Internal/External Divide. The Blackwell Guide to Epistemology. (Eds. J. Greco \& E. Sosa). Oxford: Blackwell Publishers, I45157 .

Zagzebski, L. (I999). What is Knowledge? The Blackwell Guide to Epistemology. (Eds. J. Greco \& E. Sosa). Oxford: Blackwell Publishers, 92-II6.

Öz: Bilginin edinilmesindeki 'hareket', bu yazının odak noktasıdır. Benim iddiam, soyut olsa da, bilginin edinilmesindeki hareketin iki boyutunun olduğudur: Biri "gerçekliğe doğru çalş̦an zihin" ve diğeri "akla doğru yürüyen gerçeklik". Epistemik bir yaklașım kullanarak, bu iki boyutu (bundan sonra çalıșma ve gezme anlatısı olarak anılacaktır), Dışsalcılık ve içselcilik altında bölüștürmekte ve dıșsalcılığın, bilgi edinme ile ilgili olarak, içselciliğe göre daha fazla araștırmamızı sağladığını tanımlamaktayım. Dışsalcılık, iki boyutu içselcilikten daha iyi karșılamıș gibi göründügünden, çalıșma ve yürüyüș anlatımını dıșsallık 
altında sunarım. Felsefe için çalıșma ve yürüyüș anlatımının, özellikle epistemolojinin bazı olası çıkarımları ile birlikte, öngörülen iki itiraz da ele alınmaktadir.

Anahtar Kelimeler: Epistemik çaba, bilgi edinme, dıșsalcılık, içselcilik, bilmenin ikici yolu.

${ }^{\left[{ }^{*}\right]}$ The author is grateful to Dr. Esra Akay Dağ of Sakarya University, Turkey, for her kind help on this paper. 


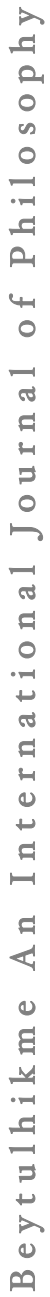

